\title{
エクセターを用いた人工股関節置換術の治療成績
}

\author{
生田拓 也* 坂 口満* \\ Clinical Results of Total Hip Arthroplasty \\ Using EXETER
}

Takuya Ikuta* and Mitsuru Sakaguchi*

Polished taper colorless type のセメントステムであるエクセターを用いた人工股関節置換術の症例 を調査し報告した. エクセターを用いた人工股関節置換術後 1 年以上経過観察できた症例 212 例を対象と した。術後経過観察期間は平均 4 年 7 ケ月であり, JOA score は術前平均 49.2 点から最終観察時平均 81.0 点に改善していた. 術中セメンティングに関しての合併症は全例において認められなかった. 術後 合併症として前方脱臼 1 例, 後方脱臼が 2 例あり, このうち前方脱臼例にソケットの再置換術を行なつた. Stem loosening 例を 2 例に認めた. Stem loosening end point とした生存率は $99 \%$, stem loosening および revision を end point とした生存率は $98.6 \%$ であった. エクセター stem を用いてセメント テクニックを適切に行い得れば良好な術後成績が期待できるものと考えられた.

We evaluated the clinical and radiographic results of total hip arthroplasty in 212 cases using Exeter type system. We followed them for a period of more than one year (average 4.6 years).

In all cases, the mean JOA score improved from 49.2 to 81.0 points. The survival rate of the femoral component due to aseptic loosening as the endpoint was $99 \%$, and that due to other causes as the endpoint was $98.6 \%$. Our findings show that the Exeter stem implanted by proper cementing technique provides excellent middle-term results.

Key words : total hip arthroplasty (人工股関節置換術)， EXETER (エクセター), clinical results (臨床成績)

\section{I.は じめ に}

Polished taper colorless type のセメントステム であるエクセターを用いた人工股関節置換術の症例を 調査したので報告する.

\section{II. 方法}

セメントステムであるエクセターを用いる選択は大 腿骨の形状および年齢にて判断している.すなわち Stovepipe canal はエクセターを, Champagne-Flute canal は他のセメントレスステムを, Normal canal は年齢に応じて若年者はよりセメントレスステムを高 齢者はよりエクセターを用いるような傾向で選択して いる.
手術体位は仰臥位で Hardinge $\mathrm{e}^{6)}$ もしくは Dall ${ }^{4)}$ の アプローチすなわち中殿筋と外側広筋の大転子付着部 の前方半分を腱性の連続性を保ちながら前方へ剥離展 開して行なっている. 臼蓋側は全例セメントレスソケッ トを用いている.

調査項目として手術前後の JOA score, レ線にて stem の設置位置, セメントの充填度, 骨/セメント 間の骨透亮帯 (radiolucent line) の発生, セメント 骨折の発生, および stem のセメント内での沈下 (stem slipping) を計測評価した。また術中および術 後合併症例, loosening 例, 再置換術例を調査した.

Stem 設置位置の計測方法として大塚らの方法 ${ }^{10)}$ (stem 軸と大腿骨長軸とのなす角度を計測し, stem の内反位をマイナス表示, 外反位をプラス表示）を用

\footnotetext{
* 熊本整形外科病院 Kumamoto Orthopaedic Hospital, Kumamoto, Japan
} 
い, セメント充填度の評価として Barrack $^{1)}$ の分類 (A：皮質骨とセメントの境界が明瞭に判定できない もの, B : 一部判別できるもの, C : 50-90\% 判別でき るもの, D : 100\% 判別できるものもしくはセメント がステム先端まで充填されていないもの）を用いた.

Stem slipping の計測方法として stem の上外側にお いて stem とセメントの間の透亮像の幅を大腿骨長軸 と平行に計測した（図1）.

\section{III. 症 例 の 概 要}

エクセターにて手術を施行した THA の症例は 2000 年 8 月から 2010 年 12 月までに 379 例で, この うち primary の症例で術後 1 年以上経過観察できた 症例 212 例を対象とした。

男性 18 例, 女性 194 例, 平均年齢は 70.1 歳であり, 術後経過観察期間は平均 4 年 7 ケ月であった.

\section{IV. 結果}

JOA score は術前平均 49.2 点から最終観察時平均 81.0 点に改善していた.

Stem の設置位置は -3 度 : 3 例, -2 度 : 10 例, -1 度 : 38 例, \pm 0 度 : 134 例, +1 度 : 22 例, +2 度 : 5 例であった.

セメント充填度は, A : 155 例, B : 56 例, C : 1 例

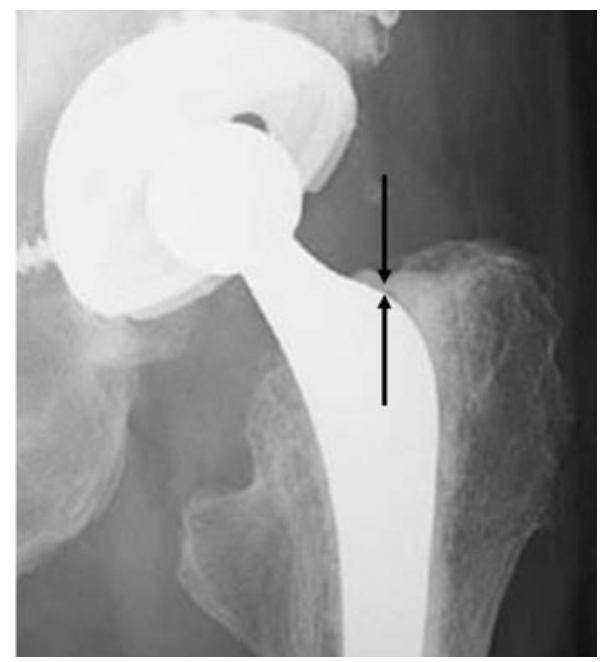

図 1 Stem slipping の計測方法 stem の上外側において stem とセメントの間 の透亮像の幅を大腿骨長軸と平行に計測した.
であつた。

Stem slipping は slippingなし：42 例，1 $\mathrm{mm}$ 以 下：166 例， $2 \mathrm{~mm}$ 以下：1例， $2 \mathrm{~mm}$ をこえるもの 3 例であった。また, Radiolucent line は zone 1 に 32 例, zone 5 に 1 例, zone 7 に 3 例認め, loosening の 1 例に全周性に認めている.

術中合併症についてであるが，術中セメンティング に関しての合併症は 212 例全例において認められなかつ た。術中に大転子の剥離骨折を 3 例に生じ, wiring を追加した. 一方, ステム挿入部の骨折は認めなかっ た.

術後合併症として前方脱臼，後方脱臼がそれぞれ 1 例あり，このうち前方脱臼 1 例にソケットの再置換術 を行なった. ソケットの loosening はなかったが, ス テムの loosening を2 例に認め, 再置換術を行なつた. これら合計 3 例に再置換術を行なつた.

また，術後大腿骨骨折を 4 例に認め骨接合術を行なつ た.このうち 1 例はステムの loosening に合併した症 例であつた。

$$
\text { V. 症例 }
$$

代表症例 63 歳, 女性, JOA score は術前 59 点 から術後 10 年時, 99 点に改善した（図 2).

再置換術例 70 歳, 女性, 術後 4 年でステムの loosening を認め, 再置換術を予定していたときに転 倒し骨幹部骨折を併発し，骨接合術と同時に IBGに て再置換術を行なった（図 3 ）。

\section{VI. 考察}

セメント使用時に血圧低下の危険性が報告されてい るが，術前に充分な補液を行う（脱水状態を起こして いない）こと，セメントプラグを使用すること，セメ ントがある程度固まった状態で stem を挿入すること などを守れば避けられ得る合併症である．我々の症例 においては術中，セメント挿入時の血圧に関する合併 症はなかった。

術中合併症としては大転子の剥離骨折を 2 例に認め たが，これは短外旋筋群の拘縮が強い症例に併発した もので，侵入方法と関連するものと考えられた. 一方, ステム挿入部の骨折は認めておらず，究極のモデュラー ステムであるセメントタイプのメリットであると考え られた。 


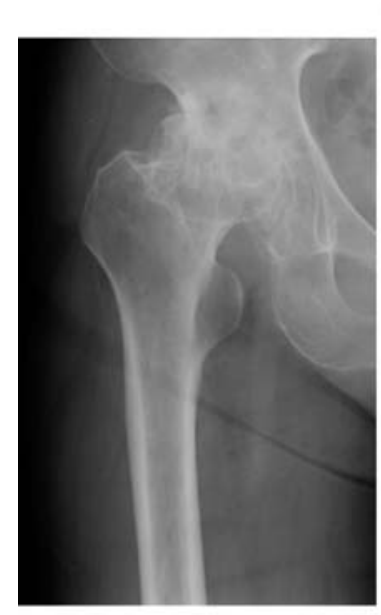

術前

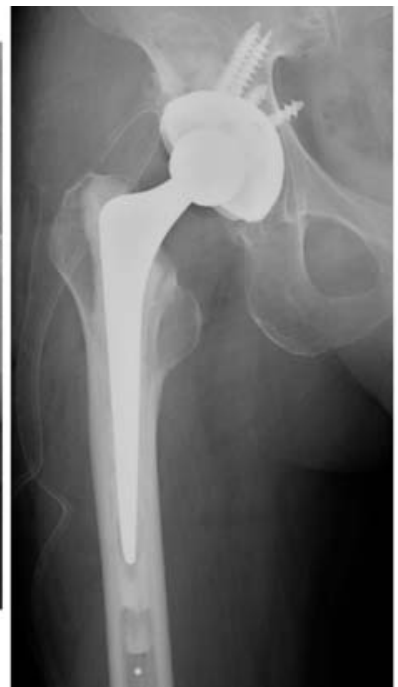

術後

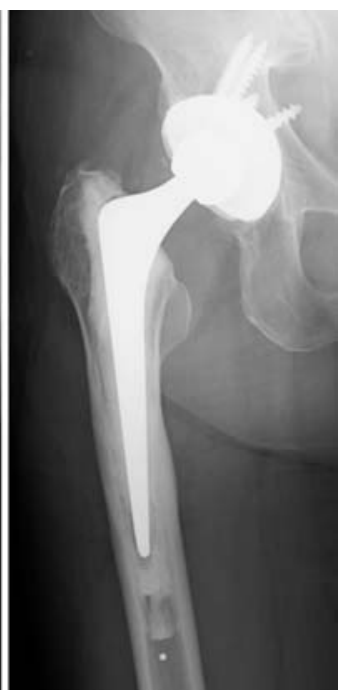

術後 10 年

図 2 代表症例, 63 歳, 女性

JOA score は術前 59 点から術後 10 年時, 99 点に改善した.

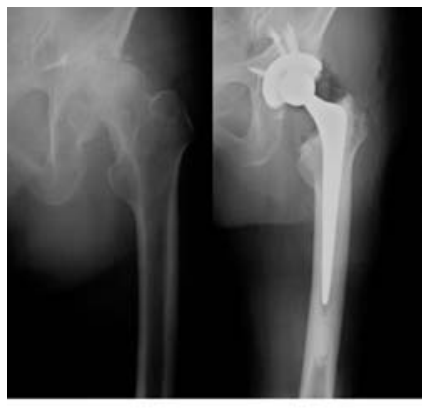

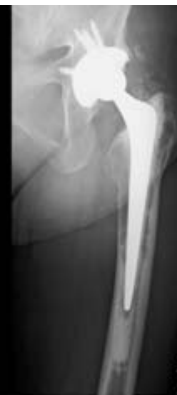

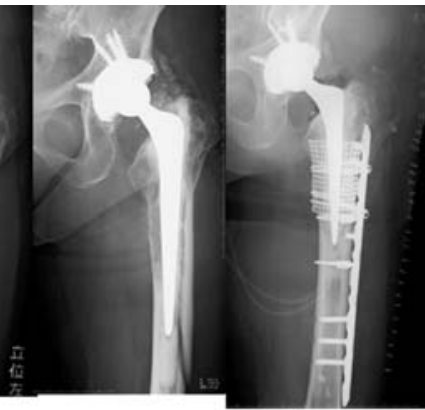

d

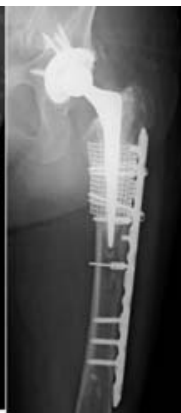

f

図 3 再置換術例, 70 歳, 女性

術後 4 年でステムの loosening を認め, 再置換術を予定していたときに転倒し骨幹 部骨折を併発し，骨接合術と同時に IBGにて再置換術を行なった.
a. 術前 b. 術後
c. 術後 4 年
d，骨幹部骨折併発
e. 再置換術後 f. 再置換術後 1 年

セメント stem であるエクセター stem の特徵35)11)

は polished surface, double tapered, colorless であ る.すなわち polished surface により stem-cement interface における磨耗が起こりにくく摩耗粉産生が 低減し, double taperにより self lockingが起こり 強固な固定となること, colorless であることにより stem の沈み込み, self locking 機構を妨げないこと である. 我々の症例においては stem slippingは 212
例中 170 例, $80.2 \%$ に認められた. 多くの症例にお いて良好な self locking が生じたものと考えられた.

一方, revision となった 2 例においてはセメントマ ントルの厚みがやや不足しており, stem slippingに よる self locking がうまく機能していないようであ り，骨セメント圧入のテクニックが未熟であったこと が原因であったかもしれない.

エクセターTHA stem における 10 年生存率は 
96〜100\% と非常に良好な報告があり 2779)111)，また，33 年での生存率が $93.5 \%$ という報告がある ${ }^{8}$. 我々の症 例においては経過観察期間が平均 4 年 7 ケ月と短期間 ではあるが, stem loosening を end point とした生 存率は $99.0 \%$ であり, これらの成績に近いものが期 待できるのではないかと考えている.すすなわちエクセ ター stem を用いてセメントテクニックを適切に行い 得れば良好な術後成績が期待できるものと考えられた.

\section{VII. ま と め}

(1)エクセターを用いた人工股関節置換術後 1 年以上 経過観察できた症例 212 例を対象とし調查した.

(2)術後経過観察期間は平均 4 年 7 ケ月であり, JOA score は術前平均 49.2 点から最終観察時平均 81.0 点に改善していた.

(3) loosening 例を 2 例に認めた. Stem loosening を end point とした生存率は 99\%, stem loosening および revision を end point とした生存率は $98.6 \%$ であった.

(4)エクセター stem を用いてセメントテクニックを 適切に行い得れば良好な術後成績が期待できるものと 考えられた.

\section{参 考 文 献}

1) Barrack, R. L., Mulroy, R. D., Harris, W. H.: Improved cementing techniques and femorai component loosening in young patients with hip arthroplasty. J. Bone Joint Surg. Br., 74 : 385-389, 1992.

2) Carrington, N.C., et al.: The Exeter universal cemented femoral component at 15 to 17 years. J. Bone Joint Surg. Br., 91 : 730-737, 2009.

3) Crawford, R.W., et al.: Fluid flow around model femoral surface finishes. Acta Orthop. Scand., 70 : 589-595, 1999.

4) Dall, D.: Exposure of the hip by anterior ostetomy of the greater trochanter. J. Bone Joint Surg. Br., 68 : 382-386, 1986.

5) Fowler, J.L., et al.: Experience with the Exeter total hip replacement since 1970. Orthop. Clin. North Am., $19:$ 25-37, 1988.

6) Hardinge, K.: The direct lateral approach to the hip. J. Bone Joint Surg. Br., 64 : 17-19, 1982.

7) Hook, S., et al.: The Exeter universal stem:a minimum ten-year review from an independent centre. J. Bone Joint Surg. Br., 88 : 1584-1590, 2006.

8) Ling, R.S., et al.: The long-term resuits of the original Exeter polished cemented femoral component. J. Arthroplasty, 24(4) : 511-517, 2009.

9) Malchau, H., et al.: Prognosis of total hip replacement. Update and validation of results from the Swedish National Hip Arthroplasty Registry 1979-1998. 67 $7^{\text {th }}$ Annual Meeting AAOS: 2000.

10）大塚博巳ら : Exeter stem の X 線学的短期成績. Hip Joint, $32: 504-508,2006$.

11) Williams, H. D., et al.: The Exeter universal cemented femoral component et 8 to 12 years. A study of the first 325 hips. J. Bone Joint Surg. Br., $84: 324-334,2002$. 